\title{
PENGARUH BAHAN ELEKTRODE PADA PENGAMBILAN Cu DAN Cd SECARA ELEKTROKIMIA
}

\author{
Abdul Haris, Melani Suberta, Didik Setiyo Widodo \\ Laboratorium Kimia Analitik Jurusan Kimia FMIPA Universitas Diponegoro
}

\begin{abstract}
ABSTRAK
Pengolahan biji tembaga menjadi tembaga banyak dilakukan menggunakan proses pemekatan melelui pencucian dan pemisahan secara fisik dengan hasil yang tidak maksimal karena sebagian logam ikut terbuang bersama pengotor logam yang lain, diantaranya kadmium ke dalam ekosistem darat dan perairan.

Telah dilakukan penelitian tentang pengaruh bahan elektroda pada pengambilan tembaga dan kadmium dari campuran dengan komposisi elektrolit $\mathrm{CuSO}_{4}$ dan $\mathrm{CdSO}_{4}$ secara elektrolisis. Sel elektrolisis menggunakan variasi bahan elektroda tembaga- karbon $(\mathrm{Cu}-\mathrm{C})$, seng - karbon $(\mathrm{Zn}-\mathrm{C})$ dan karbon-karbon $(C-C)$. Elektrolisis dijalankan dengan potensial terpasang tetap pada temperatur kamar selama 2 jam.

Hasil penelitian diperoleh bahwa kuantitas pengendapan tembaga terbaik pada elektrode $(\mathrm{Zn}-\mathrm{C})$ dapat menurunkan kadar $\mathrm{Cu}^{2+}$ dari 63,5 ppm menjadi 41,5 ppm dengan efisiensi arus 32,0\%, dan elektrode $(\mathrm{Cu}-\mathrm{C})$ dapat menurunkan kadar $\mathrm{Cd}$ dari 112,4 ppm menjadi 94,4 ppm dengan efisiensi arus $3,8 \%$
\end{abstract}

Kata kunci: tembaga, kadmium, elektrolisis, bahan elektroda

\section{THE EFFECT OF ELECTROD MATERIALS ON Cu AND Cd UPTAKE BY ELECTROCHEMICAL METHOD}

\begin{abstract}
ABSTRACK
Copper ore treatment to become copper has astonishingly been done via preconcentration followed by washing and separating process physically resulted in less quantity product. That procedure liberates waste containing the metal and other impurity such as cadmium to environment.

Research on effect of the electrode material has been performed in uptaking $\mathrm{Cu}$ and $\mathrm{Cd}$ in solution of $\mathrm{CuSO}_{4}$ and $\mathrm{CdSO}_{4}$ with electrolysis method. Electrolysis cell was constructed with varying electrode material of $\mathrm{Cu}-\mathrm{C}, \mathrm{Zn}-\mathrm{C}$ and $\mathrm{C}$-C. Process was completed at constant applied potential and room temperature within 2 hours.

Data show that best process with the use of $\mathrm{Zn}$-C electrode decreased $\mathrm{Cu}^{2+}$ concentration from 63.5 to $41.5 \mathrm{ppm}$ with current efficiency of $32.0 \%$, while in the sistem with $\mathrm{Cu}$-C electrode decreased $\mathrm{Cd}^{+2}$ concentration from 112.4 to 94.4 ppm with current efficiency of $3.8 \%$.

Keywords: copper, cadmium, electrolysis, electrode material

\section{PENDAHULUAN}

Pencemaran lingkungan dapat disebabkan oleh logam-logam berat diantaranya adalah logam berat tembaga dan kadmium yang terdapat pada limbah cair. Jumlah logam tembaga dan kadmium yang diperbolehkan terakumulasi dalam air berturut-turut adalah 1,3 dan 0,8 ppm dan bila lebih akan bersifat toksik dan dapat menyebabkan gangguan tertentu pada mahluk

hidup, sehingga diperlukan langkah-langkah pencegahan berupa pengambilan atau pemisahan logam berat tersebut.

Pengambilan logam dalam campurannya dengan metode elektrokimia dapat dilakukan pada kondisi optimal meliputi pengaruh kuat arus, potensial terpasang, $\mathrm{pH}$ larutan elektrolit, adanya ligan tertentu, elektrolit pendukung, dan bahan elektroda. Pengaruh potensial terpasang
\end{abstract}


terhadap pengendapan tembaga dan perak dalam campuran perak nitrat dan tembaga sulfat telah dilakukan Wida (2003) menggunakan elektrode platina dan karbon diperoleh hasil maksimum pada potensial terpasang 0,8 dan 1,80 volt. Pada penelitian ini akan dilakukan pemisahan dan penentuan tembaga dan kadmium dengan cara elektrolisis dari suatu larutan yang mengandung campuran kedua ion logam tersebut. Kedua ion logam diendapkan dengan variasi bahan elektroda pada potensial dekomposisi masingmasing. Pada keadaan standar besarnya potensial sel pada pengendapan $\mathrm{Cu}$ secara teoritis dapat dihitung:

Kat $: \mathrm{Cu}^{2+}{ }_{(\mathrm{aq})}+2 \mathrm{e}^{-} \rightarrow \mathrm{Cu}_{(\mathrm{s})} \quad \mathrm{E}^{\circ}=0,34 \mathrm{~V}$

An $: \mathrm{H}_{2} \mathrm{O}_{(\mathrm{l})} \rightarrow 1 / 2 \mathrm{O}_{2(\mathrm{~g})}+2 \mathrm{H}^{+}{ }_{(\mathrm{aq})}+2 \mathrm{e}^{-} \mathrm{E}^{\circ}=-1,23 \mathrm{~V}$

$\mathrm{Cu}^{2+}{ }_{(\text {aq })}+\mathrm{H}_{2} \mathrm{O}_{(\mathrm{l})} \rightarrow \mathrm{Cu}_{(\mathrm{s})}+1 / 2 \mathrm{O}_{2(\mathrm{~g})}+2 \mathrm{H}^{+}{ }_{(\mathrm{aq})} \mathrm{E}_{\text {sel }}^{\circ}=-0,89 \mathrm{~V}$

Besarnya potensial sel pada keadaan standar pada pengendapan $\mathrm{Cd}$ :

Kat $: \mathrm{Cd}^{2+}{ }_{(\mathrm{aq})}+2 \mathrm{e}^{-} \rightarrow \mathrm{Cu}_{(\mathrm{s})} \quad \mathrm{E}^{\circ}=-0,40 \mathrm{~V}$

$\frac{\mathrm{An}: \mathrm{H}_{2} \mathrm{O}_{(\mathrm{l})} \rightarrow 1 / 2 \mathrm{O}_{2(\mathrm{~g})}+2 \mathrm{H}^{+}{ }_{(\mathrm{aq})}+2 \mathrm{e}^{-} \mathrm{E}^{\circ}=-1,23 \mathrm{~V}}{\mathrm{Cd}^{2+}{ }_{(\mathrm{aq})}+\mathrm{H}_{2} \mathrm{O}_{(\mathrm{l})} \rightarrow \mathrm{Cd}_{(\mathrm{s})}+1 / 2 \mathrm{O}_{2(\mathrm{~g})}+2 \mathrm{H}^{+}{ }_{(\mathrm{aq})} \mathrm{E}^{\circ}{ }_{\text {sel }}=-1,63 \mathrm{~V}}$

Secara teoritis besarnya potensial terpasang pada pengendapan tembaga dapat dihitung dengan persamaan Nernst.

$E_{\text {sel }}=E_{\text {sel }}^{0}-\frac{0,059}{2} \log \left(\frac{P_{\mathrm{O}_{2}}{ }^{1 / 2} \cdot a_{H^{+}}}{a_{\mathrm{Cu}^{2+}}}\right)$

Pengaruh dari potensial Ohmik akan menaikkan potensial yang dibutuhkan pada sel elektrolisis sehingga diperlukan potensial luar yang lebih besar dari persamaan Nernst. Bahan elektroda yang dipergunakan dalam proses elektrolisis adalah katoda tembaga, seng dan karbon dengan anoda karbon. Dari variasi bahan elektroda yang digunakan diharapkan akan dapat diperoleh perbandingan jumlah tembaga dan kadmium yang terendapkan pada masing-masing elektroda.

Efisiensi arus merupakan besaran yang dapat digunakan sebagai salah satu parameter keberhasilan proses elektrolisis. Efisiensi arus adalah perbandingan antara jumlah materi yang terendapkan secara aktual dengan jumlah materi yang didapatkan melalui perhitungan teoritis (Khosla, 1988). Efisiensi arus dapat dituliskan dengan persamaan:

$\eta \quad=\frac{\mathrm{W}_{\mathrm{obs}}}{\mathrm{W}_{\mathrm{calc}}} \times 100 \%$

$\eta \quad=$ efisiensi arus

$\mathrm{W}_{\mathrm{obs}}=$ berat endapan hasil percobaan (gram)

$\mathrm{W}_{\text {calc }}=$ berat endapan hasil perhitungan (gram)

Dengan variasi bahan elektroda yang digunakan diharapkan akan dapat dipilih elektroda yang mampu mengendapkan tembaga dan kadmium dengan efisiensi arus yang besar.

\section{METODE PENELITIAN}

Alat: Elektronaliser, neraca analitik Mettler A 200 dan pengaduk magnet, elektrode $\mathrm{Cu}$, $\mathrm{Zn}$ dan C serta seperangkat alat gelas. Bahan: $\mathrm{CuSO}_{4} .5 \mathrm{H}_{2} \mathrm{O}$ p.a, $\mathrm{CdSO}_{4}$ p.a, $\mathrm{H}_{2} \mathrm{SO}_{4}$ pekat, aseton dan akuades

\section{Preparasi larutan elektrolit}

Dibuat larutan $\mathrm{CuSO}_{4} 2 \times 10^{-3} \mathrm{M}$ dengan cara menimbang serbuk $\mathrm{CuSO}_{4} .5 \mathrm{H}_{2} \mathrm{O}$ sebanyak 0,6242 gram dilarutkan dengan akuades hingga $100 \mathrm{~mL}$ larutan dan diencerkan sebanyak 12,5 kali. Untuk larutan $\mathrm{CdSO}_{4} 2 \times 10^{-3} \mathrm{M}$ dengan cara menimbang serbuk $\mathrm{CdSO}_{4} .5 \mathrm{H}_{2} \mathrm{O}$ sebanyak 0,641 gram dilarutkan dengan akuades hingga $100 \mathrm{~mL}$ larutan dan diencerkan sebanyak 12,5 kali. Dibuat larutan dari campuran $25 \mathrm{~mL} \mathrm{CuSO}_{4}$ 
$2 \times 10^{-3} \mathrm{M}$ dan $25 \mathrm{~mL} \mathrm{CdSO}_{4} 2 \times 10^{-3} \mathrm{M}$, sehingga diperoleh konsentrasi ion $\mathrm{Cu}^{2+}$ dan $\mathrm{Cd}^{2+}$ masingmasing $1.10^{-3} \mathrm{M}$.

\section{Penentuan potensial dekomposisi}

Sebanyak $50 \mathrm{~mL}$ larutan dielektrolisis dengan elektrode $\mathrm{Cu}-\mathrm{C}$ pada potensial dari 0,0 volt sampai 4,0 volt dalam selang kenaikan 0,2 volt selama 2 menit. Dengan cara yang sama dilakukan dengan menggunakan material elektrode $\mathrm{Zn}-\mathrm{C}$ dan C-C.

\section{Pengendapan $\mathrm{Cu}$ dan $\mathrm{Cd}$ secara elektrolisis}

Sebanyak $50 \mathrm{~mL}$ larutan dielektrolisis dengan elektrode $\mathrm{Cu}-\mathrm{C}$ pada potensial dekomposisi $\mathrm{Cu}$ dan Cd pada suhu kamar selama 2 jam. Dengan cara yang sama dilakukan dengan menggunakan material elektrode $\mathrm{Zn}-\mathrm{C}$ dan C-C.

\section{HASIL DAN PEMBAHASAN}

Saat elektrolisis berlangsung, pada anoda karbon terjadi proses oksidasi air $\left(\mathrm{H}_{2} \mathrm{O}\right)$ menghasilkan gas oksigen $\left(\mathrm{O}_{2}\right)$ sedangkan pada katoda diharapkan hanya terjadi reduksi kation $\mathrm{Cu}^{2+}$ dan $\mathrm{Cd}^{2+}$ menghasilkan lapisan padat $\mathrm{Cu}$ dan $\mathrm{Cd}$.

Reaksi dapat berlangsung, jika nilai energi bebas gibbs negatif. Oleh sebab itu diperlukan potensial luar untuk menghasilkan $\mathrm{E}^{\circ}$ sel positif. Pengaruh dari potensial Ohmik akan menaikkan potensial yang dibutuhkan karenanya dilakukan penentuan potensial dekomposisi dengan variasi elektrode sel elektrolisis pada pengendapan $\mathrm{Cu}$ dan $\mathrm{Cd}$.

Tabel 1. Potensial dekomposisi pada pengendapan $\mathrm{Cu}$ dan $\mathrm{Cd}$ terhadap variasi elektrode.

\begin{tabular}{lcc}
\hline \multicolumn{1}{c}{ Bahan } & \multicolumn{2}{c}{ Potensial Luar ( Volt) } \\
Elektrode & Cu & Cd \\
\hline $\mathrm{Cu}-\mathrm{C}$ & 2,02 & 2,60 \\
$\mathrm{Zn}-\mathrm{C}$ & 1,77 & 2,71 \\
$\mathrm{C}-\mathrm{C}$ & 1,74 & 2,44 \\
\hline \hline
\end{tabular}

Dalam sebuah sel elektrolisis, jumlah perubahan kimia yang terjadi sebanding dengan jumlah listrik yang mengalir. Namun demikian sering kali dari sekian banyak perubahan kimia yang terjadi hanya satu yang diperlukan, yaitu jumlah endapan logam pada permukaan katoda sehingga arus yang digunakan untuk perubahan kimia yang lain, misalnya pembentukan gas, dianggap sebagai pemborosan (pengurangan efisiensi).

Tabel 2. Berat endapan $\mathrm{Cu}$ dan efisiensi arus pada variasi elektrode selama 2 jam

\begin{tabular}{cccc}
\hline $\begin{array}{c}\text { Bahan } \\
\text { Elektrode }\end{array}$ & $\begin{array}{c}\text { Arus } \\
(\boldsymbol{\mu A})\end{array}$ & $\begin{array}{c}\text { Berat } \\
(\mathbf{m g})\end{array}$ & $\begin{array}{c}\text { Efisiensi } \\
(\boldsymbol{\%})\end{array}$ \\
\hline $\mathrm{Cu}-\mathrm{C}$ & 557 & 1,2 & 18,1 \\
$\mathrm{Zn}-\mathrm{C}$ & 223 & 1,1 & 32,0 \\
$\mathrm{C}-\mathrm{C}$ & 257 & 0,8 & 17,7 \\
\hline
\end{tabular}

Elektrolisis untuk pengendapan $\mathrm{Cu}$ dengan katode tembaga memberikan penampakan fisik warna kuning mengkilat, permukaan agak berpori dan kurang kuat menempel pada katode. Pada katode seng memberikan hasil endapan $\mathrm{Cu}$ yang tidak merata serta dan rapuh. Kualitas terbaik pengendapan $\mathrm{Cu}$ terjadi pada katode karbon dengan permukaan halus dan menempel dengan kuat. Efisiensi arus pada pengendapan $\mathrm{Cu}$ dari ketiga jenis elektrode sangat rendah berkisar 17-32\% hal ini dapat dijelaskan karena arus yang digunakan tidak hanya untuk reduksi ion logam menjadi logam padat, melainkan lebih banyak digunakan untuk reduksi ion hidrogen. menjadi gas hidrogen.

Tabel 3. Berat endapan Cd dan efisiensi arus pada variasi elektrode selama 2 jam

\begin{tabular}{cccc}
\hline $\begin{array}{c}\text { Bahan } \\
\text { Elektrode }\end{array}$ & $\begin{array}{c}\text { Arus } \\
(\boldsymbol{\mu A})\end{array}$ & $\begin{array}{c}\text { Berat } \\
(\mathbf{m g})\end{array}$ & $\begin{array}{c}\text { Efisiensi } \\
(\boldsymbol{\%})\end{array}$ \\
\hline $\mathrm{Cu}-\mathrm{C}$ & 109 & 0,9 & 3,8 \\
$\mathrm{Zn}-\mathrm{C}$ & 95 & 0,7 & 3,2 \\
$\mathrm{C}-\mathrm{C}$ & 106 & 0,4 & 1,5 \\
\hline
\end{tabular}

Efisiensi arus pada pengendapan $\mathrm{Cd}$ dari ketiga jenis elektrode sangat rendah berkisar 1,5-3,8\% 
dapat dijelaskan karena arus yang digunakan tidak hanya untuk reduksi ion logam menjadi logam padat, melainkan lebih banyak digunakan untuk reduksi ion hidrogen. menjadi gas hidrogen.

Elektrolisis untuk pengendapan $\mathrm{Cd}$ menggunakan elektrode ( $\mathrm{Cu}-\mathrm{C})$ menghasilkan permukaan agak berpori dan menempel dengan kuat, menggunakan elektrode (Zn-C) memberikan hasil endapan yang tidak merata serta kekuatan menempel pada katode rapuh. Kualitas terbaik pengendapan $\mathrm{Cd}$ terjadi dengan menggunakan elektrode (C-C) dengan hasil permukaan endapan halus dan menempel dengan kuat. Hasil dari penelitian didapatkan bahwa konsentrasi $\mathrm{Cu}$ dan $\mathrm{Cd}$ yang diperoleh menurun seiring dengan jenis bahan elektrode yang digunakan yaitu ( $\mathrm{Cu}-\mathrm{C}),(\mathrm{Zn}-\mathrm{C})$ dan (C-C). Penurunan berat endapan kadmium terhadap jenis elektrode yang digunakan karena setiap materi memiliki karakteristik sendiri-sendiri seperti sifat kelistrikan, rapat materi bahan, sifat unsur penyusunnya, porositas dan ikatan kimia yang ada.

\section{KESIMPULAN}

Berdasarkan penelitian dapat disimpulkan bahwa pengendapan $\mathrm{Cu}$ dan $\mathrm{Cd}$ dapat dilakukan dengan metode elektrolisis pada potensial terpasang tetap dengan berbagai variasi bahan elektrode ( $\mathrm{Cu}-\mathrm{C}),(\mathrm{Zn}-\mathrm{C})$ dan (C-C). Efisiensi arus pada pengendapan $\mathrm{Cu}$ dan $\mathrm{Cd}$ dengan menggunakan ketiga jenis elektrode sangat rendah berkisar kurang dari $32 \%$ hal ini dapat dijelaskan karena arus yang digunakan tidak hanya untuk reduksi ion logam menjadi logam padat, melainkan lebih banyak digunakan untuk reduksi ion hidrogen. menjadi gas hidrogen.
Kualitas pengendapan tembaga terbaik pada elektrode (C-C), dapat menurunkan kadar $\mathrm{Cu}$ dari 63,5 ppm menjadi 41,5 ppm, dan kadar Cd dari 112,4 ppm menjadi 94,4 ppm, sedangkan kadar logam $\mathrm{Cu}$ dan $\mathrm{Cd}$ yang diperbolehkan terakumulasi dalam air berturut-turut adalah 1,3 dan $0,8 \mathrm{ppm}$, sehingga dengan optimasi dari variasi elektrode belum dapat mengurangi kadar $\mathrm{Cu}$ dan $\mathrm{Cd}$ dibawah batas ambang yang diijinkan.

\section{SARAN}

Perlu dilakukan penelitian untuk menentukan kondisi optimal dengan penambahan ligan pengompleks tertentu untuk ion $\mathrm{Cu}^{2+}$ dan $\mathrm{Cd}^{2+}$ dalam larutan.

\section{UCAPAN TERIMAKASIH}

Ucapan terimakasih penulis haturkan kepada Kepala Laboratorium Kimia Analitik yang telah memberikan sarana dalam penelitian ini dan kepada Bapak Ismiyarta, M.Si atas saran dan koreksi demi kesempurnaan tulisan ini.

\section{DAFTAR PUSTAKA}

Bard, J.A., Faulkner, R.L., 1980, Electrochemical Method: Fundamentals and Applications, John Wiley and Sons Inc, New York, p. 16.

Couper, A.M., Pletcher, D., Walsh, F.C., 1990, Electrode Material for Electrosynthesis, Chem.Rev., 90, p. 837-865.

Crow, D.R., 1988, Principles and Application of Electrochemistry; Chapman and Hall Inc, London, p. 200-201.

Potter, E.C., 1971, Electrochemistry Principles and Application, Cleaver Hume Press Ltd, London, p. 355-356.

Sanders, A.H., 1984, Elecroplating, International Text Book Comp, Seranton, p. 32-34;53-54. 